\title{
Crystal Structure of $\mu$-Oxo-Bis[aquapyridine-2,6-dicarboxylato- antimony(III)]
}

\author{
Hossein Aghabozorg, ${ }^{* \dagger}$ Parvaneh Dalir KheIrollahi, $*$ Abolghasem MoghimI, ${ }^{* *}$ and \\ Elahe SADR-KHANLOU*
}

*Department of Chemistry, Teacher Training University, Tehran, Iran

**Department of Chemistry, University of Imam Hossein, Tehran, Iran

\begin{abstract}
The crystal structure of $\left[\mathrm{Sb}(\mathrm{pydc})\left(\mathrm{H}_{2} \mathrm{O}\right)\right]_{2} \mathrm{O}$ was determined by X-ray diffraction. This compound crystallizes in the monoclinic system, space group $P 2{ }_{1} / n$, with the following unit-cell parameters: $a=5.234(1) \AA, b=11.164(2) \AA, c=$ 14.331(3) $\AA, \beta=97.49(3)^{\circ}$. The final $R$ value is 0.0384 with 1226 reflections. This compound is a five-coordinated binuclear complex in which each of the two metal fragments are arranged via weak intermolecular Sb... $\mathrm{O}$ interactions. The binuclear units join together by axial $\mathrm{Sb}-\mathrm{O}$, and thus make a distorted square pyramid binuclear complex. The existence of a hemi-directed configuration in the complex is due to the activity of the lone electron pair on antimony.
\end{abstract}

(Received December 24, 2004; Accepted March 5, 2005; Published on web May 19, 2005)

The general strategy to make a supramolecule is to use a metal ion that tends to have different coordinative structures and the appropriate ligands, which could induce intermolecular interactions, such as $\pi$ - $\pi$ stacking and hydrogen bonds. ${ }^{1}$ Our previous efforts have shown that $\mathrm{LH}_{2},\left(\text { pydaH }_{2}\right)^{2+}(\text { pydc })^{2-}$ (pyda $=2,6$-pyridinediamine, pydc $_{2}=2,6$-pyridinedicarboxylic acid) is a suitable choice, since pyda, as a Lewis base, can play an important role in the synthesis of $[\mathrm{M}(\mathrm{pydc})]^{n-}$, and also in making a hydrogen bonding network. ${ }^{2-4}$ In this article we report

Table 1 Crystal and experimental data

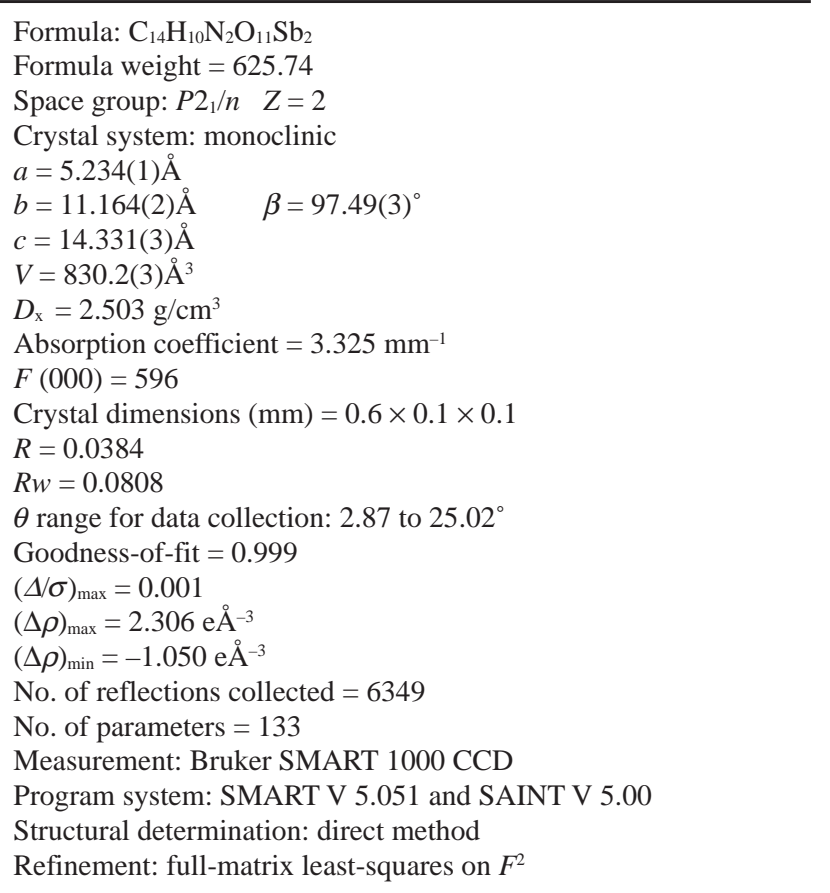

To whom correspondence should be addressed.

E-mail: aghabozorg@saba.tmu.ac.ir a complex of $\mathrm{LH}_{2}$ with antimony(III).

The titled compound was prepared by adding a solution of $\mathrm{LH}_{2}\left(2.25 \times 10^{-2} \mathrm{M}\right)$ to a solution of $\mathrm{SbCl}_{3}\left(0.025 \mathrm{~g}, 0.11 \times 10^{-3}\right.$ mol) in water. Stirring for a few minutes resulted to a white suspension. After 5 days, shiny yellow crystals were obtained. They were collected, washed with distilled water and dried. The resulting complex decomposed at over $214^{\circ} \mathrm{C}$. The X-ray diffraction data were collected on a diffractometer (Mo $K_{\alpha}$ radiation, graphite monochromator) at $293(2) \mathrm{K}$ and $\lambda=0.71073$ $\AA$. The crystal and experimental data are given in Table 1 .

The structure was solved by direct methods using SHELXS97. ${ }^{5}$ The structure was refined by the full-matrix least-squares method. The hydrogen atoms, $\mathrm{H}(\mathrm{OW})$, involved in hydrogen bonding were located from Fourier density synthesis, and were initially refined without restrictions in the riding model. All positions of the other hydrogen atoms were calculated geometrically. The final atomic coordinates of non-hydrogen atoms are listed in Table 2. As can be seen in Fig. 1, the complex is centrosymmetric binuclear by the assistance of a

Table 2 Atomic coordinates $\left(\times 10^{4}\right)$ and equivalent isotropic displacement parameters $\left(\AA^{2} \times 10^{3}\right)$ for non-hydrogen atoms

\begin{tabular}{lllll}
\hline Atom & \multicolumn{1}{c}{$x$} & $y$ & $z$ & $U_{\text {eq }}$ \\
\hline $\mathrm{Sb}(1)$ & $2501(1)$ & $5145(1)$ & $6068(1)$ & $22(1)$ \\
$\mathrm{O}(2)$ & $-570(8)$ & $5377(4)$ & $6963(3)$ & $27(1)$ \\
$\mathrm{C}(3)$ & $-1544(12)$ & $6417(6)$ & $7079(4)$ & $27(1)$ \\
$\mathrm{C}(4)$ & $-246(11)$ & $7454(5)$ & $6643(4)$ & $23(1)$ \\
$\mathrm{N}(5)$ & $1511(9)$ & $7114(4)$ & $6108(3)$ & $22(1)$ \\
$\mathrm{C}(6)$ & $2742(12)$ & $7922(5)$ & $5646(4)$ & $25(1)$ \\
$\mathrm{C}(7)$ & $4674(11)$ & $7430(5)$ & $5047(4)$ & $24(1)$ \\
$\mathrm{O}(8)$ & $4946(8)$ & $6286(4)$ & $5084(3)$ & $25(1)$ \\
$\mathrm{C}(9)$ & $-849(12)$ & $8647(5)$ & $6756(5)$ & $27(1)$ \\
$\mathrm{C}(10)$ & $451(12)$ & $9492(6)$ & $6298(5)$ & $29(1)$ \\
$\mathrm{C}(11)$ & $2264(12)$ & $9146(5)$ & $5743(5)$ & $29(1)$ \\
$\mathrm{O}(12)$ & 0 & 5000 & 5000 & $28(1)$ \\
$\mathrm{O}(13)$ & $-3415(9)$ & $6610(4)$ & $7496(3)$ & $32(1)$ \\
$\mathrm{O}(14)$ & $5782(8)$ & $8126(4)$ & $4581(3)$ & $31(1)$ \\
$\mathrm{O}(1 \mathrm{~W})$ & $991(10)$ & $3080(4)$ & $6369(4)$ & $50(2)$ \\
\hline
\end{tabular}




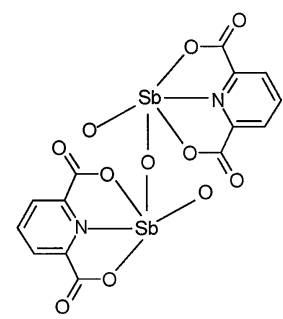

Fig. 1 Chemical structure.

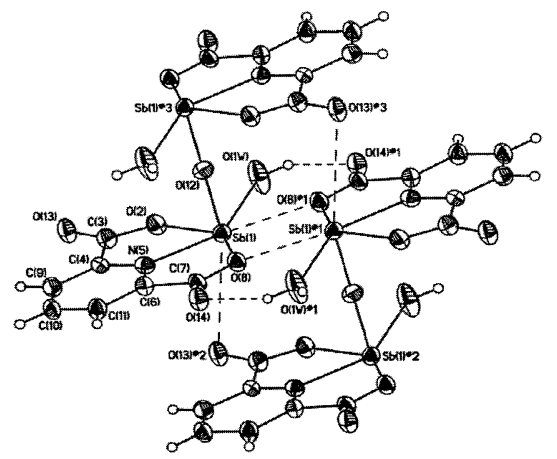

Fig. 2 Molecular structure of the $\mathrm{Sb}(\mathrm{III})$ complex with atom labeling.

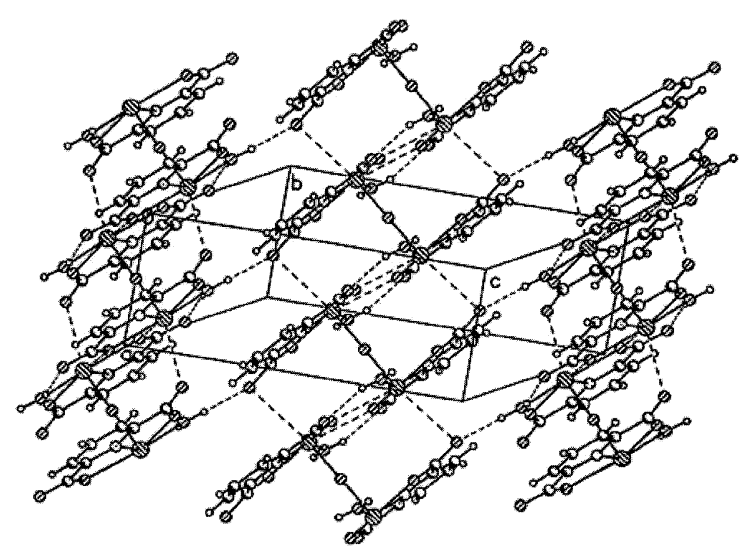

Fig. 3 Unit-cell packing diagram of the $\mathrm{Sb}(\mathrm{III})$ complex.

strong $\mathrm{Sb}(1)-\mathrm{O}(12)$ bond; the $\mathrm{O}(12)$ atom is at the center of symmetry. The binuclear units are related to each other by an inversion center, which lies at the center of the $\mathrm{Sb}_{2} \mathrm{O}_{2}$ fourmember ring. Such a ring is made by weak $\mathrm{Sb}(1)-\mathrm{O}(8) \# 1(\# 1$ : $-x+1,-y+1,-z+1)$ interactions with a distance of 2.764(4) $\mathrm{A}$. There is also a weak inter layer interaction between two binuclear units caused by $\mathrm{Sb}(1)-\mathrm{O}(13) \# 2(\# 2: x+1, y, z)$ with a distance of 3.208(5) $\mathrm{A}$. Each five-coordinated antimony is attached to a tridentate (pydc) $)^{2-}$, one water molecule and an oxygen atom remaining from $\mathrm{SbOCl}$, formed during the partial hydrolysis of $\mathrm{SbCl}_{3},{ }^{6}$ which serves as a bridge between two $\mathrm{Sb}$ atoms.

Dimerization of the antimony(III) complex can be seen in Fig. 2. The rigid tridentate coordination of the flat chelating ligand found for many metals is also seen here. Because the unit- cell packing diagram (Fig. 3) shows a layer-like structure, $\pi-\pi$ stacking is probable. However, the long distance (5.234 ̊) between two aromatic groups won't let them have effective interactions. Layers are connected via $\mathrm{O}(12)$ atoms. There is
Table 3 Selected bond lengths $(\AA)$, angles and torsion angles $\left({ }^{\circ}\right)$

\begin{tabular}{|c|c|c|c|c|c|}
\hline \multicolumn{5}{|l|}{$\mathrm{Sb}(1)-\mathrm{O}(12)$} & $1.8867(7)$ \\
\hline \multicolumn{5}{|l|}{$\mathrm{Sb}(1)-\mathrm{O}(2)$} & $2.199(4)$ \\
\hline \multicolumn{5}{|l|}{$\mathrm{Sb}(1)-\mathrm{N}(5)$} & $2.261(5)$ \\
\hline \multicolumn{5}{|l|}{$\mathrm{Sb}(1)-\mathrm{O}(8)$} & $2.391(4)$ \\
\hline \multicolumn{5}{|c|}{$\mathrm{Sb}(1)-\mathrm{O}(1 \mathrm{~W})$} & $2.493(5)$ \\
\hline \multicolumn{5}{|c|}{$\mathrm{O}(12)-\mathrm{Sb}(1)-\mathrm{N}(5)$} & $88.12(12)$ \\
\hline \multicolumn{5}{|c|}{$\mathrm{O}(12)-\mathrm{Sb}(1)-\mathrm{O}(2)$} & $90.03(12)$ \\
\hline \multicolumn{5}{|c|}{$\mathrm{O}(12)-\mathrm{Sb}(1)-\mathrm{O}(8)$} & $86.31(10)$ \\
\hline \multicolumn{5}{|c|}{$\mathrm{O}(12)-\mathrm{Sb}-(1) \mathrm{O}(1 \mathrm{~W})$} & $81.88(15)$ \\
\hline \multicolumn{5}{|c|}{$\mathrm{O}(2)-\mathrm{Sb}(1)-\mathrm{N}(5)$} & $71.55(16)$ \\
\hline \multicolumn{5}{|c|}{$\mathrm{N}(5)-\mathrm{Sb}(1)-\mathrm{O}(8)$} & $68.86(16)$ \\
\hline \multicolumn{5}{|c|}{$\mathrm{O}(8)-\mathrm{Sb}(1)-\mathrm{O}(1 \mathrm{~W})$} & $143.20(15)$ \\
\hline \multicolumn{5}{|c|}{$\mathrm{O}(1 \mathrm{~W})-\mathrm{Sb}(1)-\mathrm{O}(2)$} & $74.94(16)$ \\
\hline \multicolumn{5}{|c|}{$\mathrm{Sb}(1)-\mathrm{O}(12)-\mathrm{Sb}(1) \# 3$} & 180.0 \\
\hline \multicolumn{5}{|c|}{$\mathrm{O}(12)-\mathrm{Sb}(1)-\mathrm{N}(5)-\mathrm{C}(4)$} & $93.2(4)$ \\
\hline \multicolumn{5}{|c|}{$\mathrm{O}(12)-\mathrm{Sb}(1)-\mathrm{N}(5)-\mathrm{C}(6)$} & $-90.1(4)$ \\
\hline \multicolumn{5}{|c|}{$\mathrm{O}(12)-\mathrm{Sb}(1)-\mathrm{O}(2)-\mathrm{C}(3)$} & $-85.8(4)$ \\
\hline \multirow{2}{*}{\multicolumn{5}{|c|}{$\mathrm{O}(12)-\mathrm{Sb}(1)-\mathrm{O}(8)-\mathrm{C}(7)$}} & $91.4(4)$ \\
\hline \multirow{2}{*}{\multicolumn{3}{|c|}{$\begin{array}{l}\mathrm{O}(1 \mathrm{~W})-\mathrm{Sb}(1)-\mathrm{O}(2)-\mathrm{C}(3) \\
\mathrm{O}(1 \mathrm{~W})-\mathrm{Sb}(1)-\mathrm{O}(8)-\mathrm{C}(7)\end{array}$}} & & & $-167.4(5)$ \\
\hline \multicolumn{3}{|c|}{$\mathrm{O}(1 \mathrm{~W})-\mathrm{Sb}(1)-\mathrm{O}(8)-\mathrm{C}(7)$} & & & $162.6(4)$ \\
\hline \multicolumn{6}{|c|}{$\# 3:-x,-y+1,-z+1$} \\
\hline \multicolumn{6}{|c|}{ Table 4 Hydrogen bonds } \\
\hline D-H & $d(D-H)$ & $d(D \ldots A)$ & $<\mathrm{DHA}$ & $\mathrm{d}(\mathrm{D} \ldots \mathrm{A})$ & A \\
\hline OIW-H1WB & 0.930 & 1.877 & 163.00 & $2.780(6)$ & O13 $[-x-1 / 2, y-1 / 2,-z+3 / 2]$ \\
\hline O1W-H1WA & 0.816 & 1.913 & 153.55 & $2.668(6)$ & $014[-x+1,-y+1,-z+1]$ \\
\hline
\end{tabular}

an intermolecular hydrogen bond, as can be seen in Table 4, between water and an oxygen atom of the carboxylate group of the tridentate $(p y d c)^{2-}$. This evidence confirms a self-assembled structure for the resulting complex.

Regarding the bond distances, bond angles and torsion angles (Table 3), a distorted tetragonal pyramidal coordination around $\mathrm{Sb}$ is observed. The base of a significantly distorted pyramid is formed by the $\mathrm{O}(2), \mathrm{O}(8), \mathrm{O}(1 \mathrm{~W})$ and $\mathrm{N}(5)$ atoms (the mean deviation of atoms from this plane is $0.053 \AA$ ), and the deviation of the $\mathrm{Sb}(1)$ and $\mathrm{O}(12)$ atoms from this plane are $0.191 \AA$ and $-1.689 \AA$, respectively. The $\mathrm{O}(12)$ atom, from $(\mathrm{SbO})^{+}$, is located orthogonal to the base plane. Most the bond angles strongly differ from ideal values of $90^{\circ}$. Considering the $\mathrm{Sb}-\mathrm{O}$ bond lengths and their meaningful difference, it is apparent that the atoms around $\mathrm{Sb}$ have a hemi-directed configuration, which means an asymmetric arrangement. The hemi direction is caused by the activity of antimony's electron lone pair. In addition, the long distances of $\mathrm{Sb}(1)-\mathrm{O}(8) \# 1$ and $\mathrm{Sb}(1)-\mathrm{O}(13) \# 2$ insist on the activity of a lone pair.

\section{References}

1. A. Mukhopadhyay, G. Padmaja, S. Pal, S. Pal, Inorg. Chem. Commun., 2003, 6, 381

2. M. Ranjbar, A. Moghimi, and H. Aghabozorg, Anal. Sci., 2003, 19, 803

3. M. Ranjbar, H. Aghabozorg, and A. Moghimi, Anal. Sci., 2003, 19, x71

4. M. Ranjbar, A. Moghimi, H. Aghabozorg, and G. P. A. Yap, Anal. Sci., 2002, 18, 219

5. G. M. Sheldrick, SHELXL-97, V 5.10, Bucker AXS Inc., Madison, WI-53719, USA, a program for refining crystal structures.

6. K. Nakamoto, "Infrared and Raman Spectra of Inorganic and Coordination Compounds," 5th ed., 1997, WileyInterscience, New York. 